\title{
The Rhetoric and Ritual of Agriculture in Antebellum South Carolina
}

\section{Citation}

Faust, Drew G. 1979. The rhetoric and ritual of agriculture in antebellum South Carolina. The Journal of Southern History 45(4): 541-568.

\section{Published Version}

http://dx.doi.org/10.2307/2207713

\section{Permanent link}

http://nrs.harvard.edu/urn-3:HUL.InstRepos:2643112

\section{Terms of Use}

This article was downloaded from Harvard University's DASH repository, and is made available under the terms and conditions applicable to Other Posted Material, as set forth at http:// nrs.harvard.edu/urn-3:HUL.InstRepos:dash.current.terms-of-use\#LAA

\section{Share Your Story}

The Harvard community has made this article openly available.

Please share how this access benefits you. Submit a story.

\section{Accessibility}




\title{
The Rhetoric and Ritual of Agriculture in Antebellum South Carolina
}

\author{
By Drew Gilpin Faust
}

"W ORDS," LITERARY CRITIC I. A. RICHARDS ONCE REMARKED, "are not a medium in which to copy life. Their true work is to restore life itself to order." Language, Kenneth Burke has concurred, may be less a way of describing reality than of creating it. Speech, the two scholars suggest, is not so much a vehicle for conveying information as a mode of social action which in conceptualizing the world imposes a particular structure and meaning upon it. If language does indeed have such social functions, historians might reasonably expect to find in periods of cultural upheaval linguistic forms that seek to ease the crisis. Designed to cope with social chaos, these verbal rituals would codify a society's most fully articulated conceptions of order and disorder-and thus its most highly developed definition of itself. ${ }^{1}$

The changes that characterized early-nineteenth-century America could not but appear threatening to a nation that had traditionally regarded the farmer as the favorite of God and agriculture as the basis of an ideal social order. The farmer's declining status amidst the rising importance of the professions, the eroding

\footnotetext{
${ }^{1}$ Richards, The Philosophy of Rhetoric (New York and London, 1936), 134; Burke, especially his discussion of "Terministic Screens" in Language as Symbolic Action: Essays in Life, Literature, and Method (Berkeley and Los Angeles, 1968), 44-62, and his discussion of "dramatism" in A Grammar of Motives (New York, 1945), xv-xviii; and $A$ Rhetoric of Motives (New York, 1950). "The things of the world," he summarizes, "become material exemplars of the values which the tribal idiom has placed upon them." Language as Symbolic Action, 361. I would like to thank Richard R. Beeman, Dan Ben-Amos, Sacvan Bercovitch, Harold J. Bershady, Henry H. Glassie, III, Rhys Isaac, Bruce Kuklick, Robert C. McMath, Jr., George C. Rogers, Jr., Charles E. Rosenberg, Allen H. Stokes, Harry S. Stout, Janet A. Tighe, Anthony F. C. Wallace, Peter H. Wood, and the Ethnohistory Workshop of the University of Pennsylvania for criticisms and comments on earlier versions of this paper. An original, much briefer version was presented at a conference on language and culture in South Carolina sponsored by the Department of Anthropology, University of South Carolina, in March 1977.
}

Ms. FAUST is assistant professor of American civilization at the University of Pennsylvania. 
preeminence of agriculture in an economy of expanding commerce and manufacturing, and the movement of population away from older areas of settlement along the eastern seaboard seemed not just to signal the overthrow of existing patterns of economic relationships but to represent the emergence of an entirely new system of values and cultural commitments. To many Americans, the situation of agriculture seemed inseparable from-and even representative of - the condition of society at large. As one New Hampshire pastor observed to a gathering of farmers, "The fields we cultivate are an emblem of the moral field of the world. The labor we bestow upon them is a striking representation of that moral and religious culture which should be given to individuals and society."'2

Because agriculture appeared to be a foundation of both social and moral order, perception of decline in its objective social and economic importance created considerable uneasiness among Americans already apprehensive about the widespread changes affecting their early-nineteenth-century world. Drastic alterations in religious outlook, family life, political relationships, and economic structures seemed a protean threat to accustomed patterns of existence. The apparent shift in the position and role of agriculture within the social order thus came to represent for many anxious Americans a far wider spectrum of uncertainties. As a result, discussion of this change was often cast in an agricultural idiom. The imagery of agriculture provided a metaphorical mode of cultural self-examination and definition; it offered symbols with which Americans apprehended their world in social and moral as well as economic terms. ${ }^{3}$

This use of agricultural terminology as a vehicle through which to formulate deep-rooted cultural anxieties appears most prominently in what was known to nineteenth-century Americans as the agricultural address. Delivered at ceremonial gatherings of agricultural societies in all sections of the nation, these addresses constituted a specific oratorical genre that followed a prescribed pattern both of form and subject matter. Reflecting in their style and content many of the era's most deeply felt concerns, the speeches became, moreover, the focal point of a social ritual designed to confront and resolve many of the same issues of status and value articulated in the addresses themselves. Taken together, the agri-

2 Humphrey Moore, An Address Delivered at Hopkinton, Before the Hillsborough Society . . October 17, 1821 (Amherst, N. H., 1822), 13.

${ }^{3}$ For specific discussion of the meaning of these changes to the South see Drew Gilpin Faust, A Sacred Circle: The Dilemma of the Intellectual in the Old South, 1840-1860 (Baltimore and London, 1977). 
cultural orations and their social setting within agricultural gatherings constitute what sociolinguist Dell Hathaway Hymes has called a "speech event." The agricultural address was an act of verbal communication that served as a particular focus of social interaction, while at the same time the substance of the oration formulated the wider patterns of cultural values within which this immediate social reality was located. The rhetoric and the ceremony that bracketed it therefore manifested the interaction of language and culture through the designation of agriculture as both verbal and ritual symbol.4

While the relationship of language to culture and society is evident in agricultural addresses delivered throughout antebellum America, the specific details, the texture and meaning of the confrontation with change differed from region to region. While the nation as a whole had shared a common agricultural heritage, the social and economic implications of this traditional commitment differed markedly in North and South. And while Americans throughout the nation confronted disquieting change in the antebellum period, the particular shape of progress was to vary considerably between the growing commercial and industrial civilization

\footnotetext{
- The approach taken in this paper has been greatly influenced by Dell Hymes's formulations of the methodology of "the ethnography of speaking" in Foundations in Sociolinguistics: An Ethnographic Approach (Philadelphia, 1974). See also Richard Bauman and Joel Sherzer, eds., Explorations in the Ethnography of Speaking (Cambridge, Eng., 1975). On genre see Dan Ben-Amos, "Analytic Categories and Ethnic Genres," Genre, II (September 1969), 275-301; Roger D. Abrahams, "The Complex Relations of Simple Forms," ibid., (June 1969), 104-28; and Abrahams, "Introductory Remarks to a Rhetorical Theory of Folklore," Journal of American Folklore, LXXXI (April-June 1968), 143-58. See also Maurice Bloch, ed., Political Language and Oratory in Traditional Society (London, 1975); J. L. Austin, How to Do Things with Words (Cambridge, Mass., and London, Eng., 1962); S. J. Tambiah, "The Magical Power of Words," Man, N.S., III (June 1968), 175-208; John R. Searle, Speech Acts: An Essay in the Philosophy of Language (London, 1969); Michelle Rosaldo, "I Have Nothing to Hide: The Language of Ilongot Oratory," Language in Society, II (October 1973), 193-223; Peter Seitel, "Haya Metaphors for Speech," ibid., III (April 1974), 51-67; Max Black, Models and Metaphors: Studies in Language and Philosophy (Ithaca, 1962); Stephen C. Pepper, World Hypotheses: A Study in Evidence (Berkeley and Los Angeles, 1942); James W. Fernandez, "Unbelievably Subtle Words: Representation and Integration in the Sermons of an African Reformative Cult," History of Religions, VI (August 1966), 43-69; Fernandez, "Poetry in Motion: Being Moved by Amusement, by Mockery and by Mortality in the Asturian Countryside," New Literary History, VIII (Spring 1977), 459-80; Fernandez, "Symbolic Consensus in a Fang Reformative Cult," American Anthropologist, LXVII (August 1965), 902-29; Fernandez, "The Mission of Metaphor in Expressive Culture," Current Anthropology, XV (June 1974), 119-45; Fernandez, "Persuasions and Performances: Of the Beast in Every Body . . . and the Metaphors of Everyman," in Clifford Geertz, ed., Myth, Symbol and Culture (New York, 1974), 39-60; and Fernandez, "The Performance of Ritual Metaphors," in J. David Sapir and J. Christopher Crocker, eds., The Social Use of Metaphor (Philadelphia, 1977). A historian who has employed this approach in the study of texts is Quentin Skinner. See his "Motives, Intentions and the Interpretation of Texts," New Literary History, III (Winter 1972), 393-408; and Skinner, "Some Problems in the Analysis of Political Thought and Action," Political Theory, II (August 1974), 277-303.
} 
of the North and the slave society of the South. While a challenge to the status of agriculture was certainly unsettling to old farm communities of New England and the Middle States, it appeared to the South as a crisis of even greater proportion, and inevitably became caught up with the region's growing consciousness of itself as a minority section in the years leading up to the Civil War. Any threat to the preeminence of agriculture was thus construed as a direct attack upon the southern way of life generally. By the early nineteenth century the South had thoroughly committed itself to an economic, social, and racial order based on profitable staple-crop agriculture carried out by a labor force of black slaves. Any alteration of these arrangements seemed to threaten what had become a comprehensive system of racial subordination and control. Thus the fear of change that existed throughout antebellum America took on a particularly intense form in the South, for change itself seemed especially menacing to a region in which violence lay as the recognized yet unspoken foundation of the social order.

The agricultural address similarly reflected these dimensions of universality and specificity. A form employed widely in both North and South, the agricultural oration was nevertheless culture and section specific; it expressed the particular response of the society in which it was articulated to a set of problems that in their most general sense confronted all Americans. But in the South this fear of change was experienced most directly as a series of immediate threats to regional confidence and even survival. Within the state of South Carolina, which remained a focus of sectional conflict from the nullification controversy in 1832 to the attack on Fort Sumter in 1861, this sense of crisis was particularly acute. Everywhere a response to change, the agricultural address in South Carolina reflected the peculiarly intense dilemmas confronted by the planter leadership of this most radical southern state. For the master class the agricultural address became a jeremiad, a lamentation of regional failure as well as a call for South Carolinians to reclaim their rightful place as the chosen people of God. Through verbal symbols, planters imbued the soil that supported them with spiritual meaning and transformed nature into both a model of and a model for their social and moral lives. ${ }^{5}$

\footnotetext{
"I am much indebted to Clifford Geertz for the "model of/model for" conceptualization of the way belief systems operate. See Geertz, The Interpretation of Cultures: Selected Essays (New York, 1973), 118. On the jeremiad see Sacvan Bercovitch, "Horologicals to Chronometricals: The Rhetoric of the Jeremiad," Literary Monographs, III (1970), 33; Bercovitch, The American Jeremiad (Madison, Wis., 1978); and Perry Miller, The New England Mind: From Colony to Province (Cambridge, Mass., 1953), 29-52. I do not intend
} 
The purpose of this essay will be to explore the role and meaning of these orations within increasingly sectionalist South Carolina, where the vicissitudes of agriculture correlated directly with alternating moods of cultural chauvinism and despair. A description of the formal structure of the agricultural address and its relationship to the ritual of the agricultural society meetings where it was delivered will suggest a way in which language may become part of a continuum of social action. A case study of South Carolina, moreover, may serve to elucidate how a single American subculture defined itself in response to processes of change and to suggest how its peculiar employment of a nationally utilized genre simultaneously reflected both the area's uniquenes and its typicality. The agricultural oration in this sense embodied the dialectical relationship between nationalism and sectionalism so central to the culture of the Old South. ${ }^{6}$

The severe agricultural depression of the late thirties and early forties came as a climax to twenty years of uncertainty in the cotton market. After the nationwide financial panic of 1819 cotton prices never regained the heights of the first decades of the century. Despite signs of a reviving market in the mid-thirties, prices had by the end of that decade begun a precipitous decline that was further accelerated by the national economic crisis beginning in 1837. With only brief interruptions the cotton market remained depressed until the 1850s. Before about 1826 increasing productivity had somewhat compensated for the drop in price, but after that year South Carolina's output of cotton declined as well, and it continued to decline for the next fifteen years. ${ }^{7}$

to indicate an exact identity between the Puritan jeremiad and the Carolina agricultural address. The Puritan "plain style" was in structure and expression quite different from the Classical rhetoric that influenced the Carolinians. Rather, I see a more general similarity, a parallel in modes of perception much like what Bercovitch has referred to as "the Puritan origins of the American self." See Bercovitch, The Puritan Origins of the American Self (New Haven and London, 1975); and David Minter, "The Puritan Jeremiad as a Literary Form," in Bercovitch, ed., The American Puritan Imagination: Essays in Revaluation (London, 1974), 44-55.

- On the recurrent crises within South Carolina see William W. Freehling, Prelude to Civil War: The Nullification Controversy in South Carolina, 1816-1836 (New York and London, 1965); and Steven A. Channing, Crisis of Fear: Secession in South Carolina (New York, 1970).

' On the economic situation in South Carolina in this period see Alfred G. Smith, Jr., Economic Readjustment of an Old Cotton State: South Carolina, 1820-1860 (Columbia, 1958); Marjorie S. Mendenhall, "A History of Agriculture in South Carolina, 1790 to 1860: An Economic and Social Study" (unpublished Ph.D. dissertation, University of North Carolina, 1940); Arthur R. Hall, The Story of Soil Conservation in the South Carolina Piedmont, 1800-1860 (U. S. Department of Agriculture, Miscellaneous Publication, No. 407: Washington, 1940). I have not discussed rice production here. Rice prices remained steadier than cotton, but rice lands were beginning to suffer from neglect as well. 
In the early thirties the tendency of South Carolinians to fix blame for their difficulties on oppressive tariffs imposed by the North led to the upheavals of the nullification movement. But when a compromise tariff did not bring economic revival South Carolina's planters began to search for other explanations of their predicament. Compared with fresh lands in the southwestern states of Alabama and Mississippi, overworked Carolina soil seemed exhausted, clearly incapable of competing in productivity per hand or per acre. "The sterile aspect of the country . . .," one planter observed, "indicates too truly our wretched system of agriculture, and the necessity of an immediate change if we wish to preserve the little remnant of fertility still left in our lands.",8

With the effects of western competition magnified by falling prices, Carolinians sought to account for the depressed state of the cotton market. "It is a well-known fact," one orator reminded his audience, "than [sic] the quantity of cotton already grown is fully equal to the consumption, and by many, it is believed, to exceed it." The golden age of cotton, it seemed, had passed. The planters of South Carolina, James Henry Hammond warned, "will be speedily compelled almost, if not altogether, to abandon its longer cultivation." 9

Yet the state's agriculturists acknowledged that they were peculiarly unequipped to deal with cotton's demise. Their reliance upon the staple was so exclusive that they found themselves "tributaries" to other regions of diversified economies both for many foodstuffs and for nearly all manufactures. "It is the true policy of the cotton planters," resolved an agricultural convention in 1843 , "to curtail the cotton crop and increase the provision cropso as to supply all the breadstuffs and raise all the different kinds of stock ... which may be necessary for family and plantation use." 10

See Mendenhall, "A History of Agriculture," 338; and Black Oak Agricultural Society Minutes, 1842-44 (South Carolina Historical Society, Charleston, S. C.). There is a vigorous debate at present about the dimensions and reality of "decline" in the southern economy. For a discussion of this see Faust, $A$ Sacred Circle, 156, n. 19. Carolinians unquestionably perceived a decline in comparison with past prosperity.

B W.A.G., "On Manures," Southern Agriculturist, VI (March 1833), 122.

9 Agricola, "Observations on the Present Condition of the Southern States," ibid., VII (June 1834), 287; Hammond, "Anniversary Oration of the State Agricultural Society of South Carolina . . . 25th November, 1841," in The Proceedings of the Agricultural Convention and of the State Agricultural Society of South Carolina from 1839 to 1845 Inclusive (Columbia, 1846), 182. The preceding volume will be cited hereinafter as Proceedings.

${ }^{10}$ Quotations in this paragraph are in order from "Proceedings of the South-Carolina Agricultural Society," Southern Agriculturist, N.S. III (August 1842), 397; “Agricultural Convention, Monticello, Fairfield District, July 5, 1843," clipping in Private Diary of Edmund Ruffin, State Agricultural Surveyor of South Carolina, 1843, Edmund Ruffin Papers (Virginia Historical Society, Richmond, Va.). 
These structural deficiencies in South Carolina's agricultural economy seemed to perceptive analysts the cause of another alarming development. The productivity of western land was not only capturing the cotton market, it was attracting many of South Carolina's most industrious and enterprising citizens. The problem of emigration from Carolina was so severe that by 1850 the census revealed that of all living Americans born in South Carolina, 41 percent had moved elsewhere. The slow growth of population took on ominous meaning when South Carolina lost two representatives in congressional reapportionment. ${ }^{11}$

Prevailing agricultural practices contributed significantly to these harsh economic and demographic realities. Most Carolinians had little understanding of soil chemistry and clung to what State Agricultural Surveyor Edmund Ruffin described as the "barbarous usage" of growing cotton on the same land every year. Even those who did practice rotation of crops tended to follow one exhausting product with another, little understanding the principles behind variation in planting. Carolinians retained as well an almost "universal prejudice" against the plow, so that even when fertilizer was applied to the soil, it was not effectively worked in. Shallow cultivation also contributed to extensive erosion, as rains washed loose topsoil into rivers and streams. Because of this "ignominious course of culture" an agricultural journal estimated in 1850 that 800,000 "square acres" of Carolina land had been entirely worn out-or at least seemed effectively exhausted because of an inability to compete in productivity with virgin lands in the West. ${ }^{12}$

Severe as they appeared, the realities of soil depletion and declining profits seemed to agricultural orators as only a part of the crisis afflicting the state. Behind these obvious difficulties lay another, less apparent dimension of Carolina's dilemma. Those who discussed her plight rarely restricted their analyses to social and economic concerns. Orators defined the agricultural situation in moral terms; speakers sought to describe Carolina's condition in language that would contain implicit within it a strategy of action for dealing with the crisis at hand. The constantly reiterated threat of both moral and economic "despair and ruin" was intended to compel Carolinians to the reform that was presented as their only

\footnotetext{
"For statistics on population decline see Mendenhall, "A History of Agriculture," 195; and Smith, Economic Readjustment, 19-44.

12 Quotations in this paragraph are in order from Ruffin, Private Diary, 107, 117; "Claims of the Agricultural Interests to Legislative Aid," Farmer and Planter, I (November 1850), 138. See also Hall, The Story of Soil Conservation.
} 


\section{salvation. ${ }^{13}$}

Agricultural decline, these orators found, challenged an entire system of values; it called into question not just men's means of relating to the soil but their relationships with one another and with God. Like Puritan jeremiads, lamentations of degeneration in agricultural addresses equated material with spiritual blessings, identifying economic decline as both symbol and consequence of social disharmony and moral decay. It was an error, one speaker warned, that "instead of looking to ourselves for a want of success, [we] attribute the failure to our lands-we proclaim them sterile ...."'14

Agriculture and its failures could not be separated from man's moral condition; the land necessarily influenced and reflected man's spiritual nature. These rhetorical formulae defined agriculture as the cornerstone of society itself, not simply through its provision of the material bases of life but through "its great and primary value, in affecting the condition of the human family, and conserving the social harmonies, and promoting and sustaining the moral basis" of southern civilization. The agricultural address had traditionally offered the assurance of ultimate immutability within nature's cycles of repeated decay and rebirth. To a society beset by change, the orations thus provided a familiar and comforting image of the land as a stable reality, transcending individual human lives or fortunes. The "God of Nature," a correspondent of the Southern Agriculturist contended, had made it possible for the southerner to remain aloof from the social disorders that increasingly plagued the cities of the North. Independent of other men and reliant only upon the land, the planter could be "more above the reach of contingencies than the monarch upon his throne."'15

But by the mid-thirties such a vision of stability had come to serve more as the affirmation of a consoling possibility than as a realistic description of the situation at hand. Indeed, the very appearance of change, of challenges to this ideal of eternal immutability, required agricultural rhetoric to encompass these new

\footnotetext{
13 "'Suggestions for Southern Planters," Southern Agriculturist, N.S., V (June 1845), 201. This is a process Kenneth Burke calls entitlement. The definition of a situation encompasses within it a strategy for dealing with the reality so defined. See Burke, "What Are the Signs of What? A Theory of Entitlement," in Burke, Language as Symbolic Action, 359-79.

14 "Introduction," Southern Agriculturist, IX (January 1836), i-ii.

15 Quotations are in order from "Southern Agriculture," Magnolia, IV (March 1842), 129; "Culture and Preparation of Indigo for Market," Southern Agriculturist, N.S., IV (May 1844), 186. See also William Gilmore Simms, "The Good Farmer," Ladies Companion, XV (August 1841), 156.
} 
threats within its explanatory mode. Orators of the 1830 s began to recognize that the earth had not proved unchangeable but had decayed; society had similarly been drastically altered as Carolinians abandoned their tired lands to move to the virgin soils of the West. But this had occurred, the speakers explained, because the relationship between culture and agriculture was not simply one-directional; agriculture was a reflection of society and values as well as an influence upon them. Nature's riches were not the free gift of God but demanded careful management and cultivation. "The Earth is ours as a sacred trust . . . ." Even Carolina's slave institution, orators warned ominously, seemed to be weakening, eroding like the soil because of the planter's failure to exercise his responsibility to supervise the human bounty God had entrusted to his care. The state's deficiencies, the exhaustion of her soil, the decay of her way of life, the orators argued, arose from the neglect of what were in essence religious duties. ${ }^{16}$

The rhetoric transformed failures of mind into failures of morality and thus rendered them appropriate subjects for the evangelical intervention of the agricultural orator. ". . . we have not," one Carolinian lamented, "done justice to that noble inheritance which has descended to our hands. We have, in the mournful language of scriptural self-chiding, left undone those things which we ought to have done; and we have done those things which we ought not to have done." But, he continued, departing from the Anglican prayer for absolution that he had invoked, "We will not add, that 'there is no help in us,' for we trust there is both help and hope .... in any people, who acknowledge their errors, and are . . . prepared to amend them." ${ }_{17}$

Like jeremiads, these agricultural lamentations transformed the experience of crisis into a divine warning. Depression was not a vindictive punishment or a sign of damnation, but a corrective affliction imposed, like the tribulations of Job, on God's chosen. The present situation, Basil Manly explained, "is a state of trial." South Carolinians had erred, but a final verdict had not yet been rendered; the lamentation of apostasy contained implicit within it the possibility of redemption and reform. This characterization of the situation implied a sense of human obligation, a requirement for action. "God does nothing in vain," William H. Wigg reminded the Agricultural Society of St. Luke's Parish. In Carolinia's affliction " $\mathrm{He}$ has revealed his will. $\mathrm{He}$ has made our

16 Simms, "The Good Farmer," 154.

17 "Southern Agriculture," 135-36. 
duty plain."'18

These orations were designed, like rhetoric more generally, to move humans to certain attitudes and actions. Words were intended, as Edmund Rhett explained to the Beaufort Agricultural Society, to assume "the power of things." The addresses therefore display many of the time-honored devices of traditional rhetoric learned by educated Carolinians from Classical texts. But the Carolinians' specific use of these ancient modes of persuasion demonstrate as well the speakers' understanding of the particular values most deeply cherished by their fellow citizens. ${ }^{19}$

The literary device upon which the agricultural address was founded was one that rhetoricians since the age of Aristotle have labeled "identification," an assertion of likenesses among both ideas and individuals that imparts the sense of intellectual coherence and of emotional and social unity prerequisite to common action. To advance his case a speaker redefines or reclassifies a problematical concept in terms of recognized positive affect; he moves the idea into a realm acknowledged as appealing and desirable. He "identifies" the object of his concern with the positive response actually evoked by the context in which he has placed it, and thus he demonstrates its consistency with accepted beliefs and values. At the same time, he enhances his persuasive powers by using identification in another manner as well, stressing the similarities between himself and his audience, not just in terms of belief but of more objective external factors. Thus out of both conceptual and social divisions he seeks to establish unity, imposing upon the diversity of experience a single order and meaning that will clearly prescribe future attitudes and patterns of conduct. ${ }^{20}$

South Carolina's agricultural orators sought in their use of identification to establish an ideological as well as a social consensus that would override the cultural and social conflict they found

18 Manly, "An Address on Agriculture," Southern Agriculturist, N.S., II (July 1842), 344; Wigg, "Address on the Anniversary of the Agricultural Society of St. Luke's Parish . . . 13th May, 1836," ibid., VI (July 1846), 257-58.

19 Rhett, "Agricultural Address-Entitled 'Who is the Producer?' . . August 1840," Southern Cabinet, I (December 1840), 714. This study is based on the approximately ninety complete agricultural addresses from South Carolina that I have been able to locate for this period and thirty northern addresses analyzed for comparison. Every educated South Carolinian was given at least some training in Classical rhetoric, a staple of both school and college curricula. See, for example, Daniel W. Hollis, University of South Carolina (2 vols., Columbia, 1951-1956), I, 31-32.

20 James Fernandez refers to this process as moving ideas through "quality space." See Fernandez, "Poetry in Motion," 475. For a description of this device in a text used widely in nineteenth-century South Carolina see Richard Whately, Elements of Rhetoric... (Boston, 1839), 192. 
so alarming. As historian James M. Banner, Jr., has emphasized, the emergence of black majorities in two-thirds of South Carolina's parishes by 1860 had only intensified a long-standing fear of the existence of any discord among whites. Expressed in what Banner describes as a Carolina tradition of an "antiparty ideology" and a "no-party system," these anxieties were manifested as well in the dedication of the agricultural address to the promotion of unity. Both the ideas presented within the orations and the form of the addresses themselves were designed to advance this traditional rhetorical-and social-goal.21

The structure of the genre itself reveals the most basic relationships of sameness the orators sought to present. These addresses were highly stylized, and speakers recognized that they were expected to follow certain well-established forms. When Joel Roberts Poinsett intended to deviate slightly from the explicit rules, he felt compelled to excuse himself and to explain he would not be making "what is usually called an Agricultural address." 22

Almost without exception, agricultural orations from this period in South Carolina opened with what one speaker described as an "apologetic preface." Each orator felt obligated to proclaim his "sense of . . . deficiency" at the task before him and thus to identify himself with his audience and engage their sympathies by denying his uniqueness or individuality and by portraying himself as in a sense the creation of their will. Although in New England agricultural orations were often delivered by clergyman, South Carolina's orators were almost inevitably planters-the most successful and wealthy citizens, to be sure, but, they insisted, as tillers of the soil, simply primi inter pares. Here was the persistent paradox of the South's aristocratic egalitarianism again reaffirmed; the orator sought simultaneously to be first and to be equal. The existence of class divisions in the region could be all but denied through an insistence upon the essential similarity that overrode differences not just between the highly successful agriculturist on the podium and the planters who composed most of his audience but between the richest and the poorest Carolinians. Be they wealthy planters or dirt farmers, southerners were, the myth contended, agrarians all. In these familiar terms, the orator endeavored to portray himself to-and identify himself with-both his listeners and his section. ${ }^{23}$

"1 Banner, "The Problem of South Carolina," in Stanley M. Elkins and Eric L. McKitrick, eds., The Hofstadter Aegis: $A$ Memorial (New York, 1974), 91.

22 Poinsett, “A Discourse," Southern Agriculturist, N.S., IV (December 1844), 452.

${ }^{23}$ Quotations are in order from Edward R. Laurens, "An Address Delivered Before the Agricultural Society of South Carolina, September 18, 1832," Southern Agriculturist, V 
Having emphasized this solidarity, the orator set forth upon his address, usually beginning with a paean to agriculture. "Nothing is more common on occasions like the present, than for the speaker to labour at the very outset, to impress his audience with the importance of his subject," one South Carolinian explained. Agriculture had to be transported from the realm of the mundane to a position of appropriately inspirational dignity. Orators sought regularly to accomplish this task by considering it in terms of the legitimating frameworks of history, science, and religion. ${ }^{24}$

Usually, "an historical sketch of the progress of agriculture in different ages and nations, or with abstract speculations on its antiquity, dignity and importance" immediately followed the apologetic preface. Cain, Noah, the Patriarchs, the Egyptians, the Greeks, the Romans, and America's Founding Fathers were invoked to demonstrate that in its very persistence through the ages agriculture had gained at least a degree of transcendence. As chronologically the first endeavor of mankind, orators argued, agriculture deserved to be considered the foremost. ${ }^{25}$

But agriculture was not simply legitimated by tradition; it was identified with the way of the future as well. After reiterating the history of husbandry, the oration almost inevitably included a section discussing agriculture in light of modern experimental discoveries, seeking, as Basil Manly explained, "accomplishment of an immediate and settled union between the profoundest science and the labors of the field." In associating agriculture with rational investigation the orator sought to enhance the position of husbandry by portraying it as a profession requiring knowledge and training and bestowing upon its practitioners the "dignity" accorded by the modern age to such accomplishment. ${ }^{26}$

Yet while agriculture was theoretically consistent with modern science, it was, the orators complained, rarely practiced by South Carolinians in conformity with scientific dictates. The discussion

(November 1832), 562; Daniel K. Whitaker, "An Address Delivered Before the Agricultural Society of South Carolina . . . August 20th, 1833," ibid., VI (October 1833), 505. See similar remarks by Henry Colman, "An Address Before the Hampshire, Franklin, and Hampden Agricultural Society. . . Greenfield, Mass., October 23, 1833," ibid., VII (March 1834), 139-41.

24 M. P. Crawford, An Address Delivered Before the Lancaster Agricultural Society . . . (Lancaster, S. C., 1854), 5.

${ }^{25}$ Angus Patterson, An Address to the Farmers' Society of Barnwell District . . . Second Day of January, 1826 (Charleston, 1826), 4. The textbook of rhetoric used in South Carolina College explained: "One of the objects most frequently proposed in an Introduction, is, to shew that the subject in question is important . . . and worthy of attention." Whately, Elements of Rhetoric, 113-14.

26 Manly, "An Address on Agriculture," 338. 
of agriculture in the light of history and science was thus usually structurally juxtaposed with a third section of the address lamenting existing inadequacies. Here the orator stressed the contrast between the achievements of husbandry in past ages, its future potential as a branch of science, and its manifold present deficiencies. Inspired by the account of agriculture's glorious past and its future greatness, the listener was to be moved to change the disappointing present, to make rational husbandry a reality. Science, the orator reminded his audience, promised to be more than a means to truth; it would serve as an avenue to success as well, for it was on the principles of science that the rise of the professions was founded. "You hear him [the farmer] talk," Andrew P. Calhoun declared to a gathering of planters, "of law and medicine as the two learned professions. He habitually defers to them as something superior to his own. . . . Now, cannot this be changed? Cannot the farmer and planter train his intellect ... . [?]" Agricultural orators did not doubt that "The application of science . . . will soon correct the errors of public sentiment, and organize the social relations of society on a new basis," enhancing the image of the farmer by identifying him with the march of progress that characterized the modern age. Science was desirable not only because it was true, but because it would be socially and economically profitable. ${ }^{27}$

The paean to rational knowledge that appeared in every agricultural address, however, was ordinarily cast in what the twentieth century would regard as curiously unscientific terms. The orator hoped not only to associate agriculture with both past tradition and future progress but also to unite religion with science into a single legitimating framework. "The scientific planter ....," J. Jenkins Mikell explained, could not but be aware of "the Divine mind . . . displayed before him ...." As a result, the portions of the address devoted to history and science were often followed by a specific discussion of the ties between agriculture and religion. More frequently, however, the consideration of these relationships was not restricted to a single section of the address; religious language and symbolism pervaded the entire oration, providing the terminology for much of the rest of the discussion. Science was presented as simply the modern form of divine revelation, for the farmer, as one orator affirmed, routinely "looks

\footnotetext{
${ }^{27}$ Quotations are in order from Calhoun, "Address Delivered Before the Pendleton Farmers' Society, October 13, 1855, "Farmer and Planter, VI (December 1855), 269; O. R. Broyles, "An Address Delivered Before the Anderson District Farmers Society . . . 21st November 1849," ibid., I (May 1850), 34.
} 
through nature up to nature's God." The listener had learned that improved agriculture could elevate his material condition; now he was promised that the pursuit of wealth would produce spiritual amelioration as well. In agriculture, the speakers suggested, lay the means of reconciling not just science and religion but traditional morality with the alluring materialism of the modern world. ${ }^{28}$

In a reformed agriculture and consequently replenished soil lay the resolution of all these tensions - a way of satisfying the desire for wealth within the framework of man's most time-honored occupation. The westward emigration so destructive to social order within the state would no longer be necessary, for profitable farming would be possible at home. Through agriculture, Carolina's planters assured themselves, they could be rich without succumbing to corrupt materialism. Under such circumstances, riches would serve as testimony to their spiritual excellence and favor with God. Planting, Whitemarsh Benjamin Seabrook affirmed before the United Agricultural Society, was one "business, which of all others, best conduces to the legitimate purposes of man's creation."'29

Through the symbolic identification of nature, society, and God, moral commitment was defined as being as important as the very nourishment man derived from the earth. The agricultural jeremiad served, in the words of anthropologist Victor Turner, as a "mechanism that ... converts the obligatory into the desirable." Like the ritual and symbolic forms Turner has described among African peoples, the structure of the agricultural address juxtaposed and thus associated ethical norms with the emotional allurements of financial profit. Duty was defined as a pleasure and pleasure as a duty. James Henry Hammond of South Carolina neatly exemplified the way such symbols work when in 1841 he explained the effects of casting what modern Americans would regard as economic problems in social and religious terms. Agricultural decline, he proclaimed, "cannot be contemplated but with feelings of profound emotion. Not only on account of its

${ }^{28}$ Quotations are in order from Mikell, "Address Delivered Before the Agricultural Society of St. John's Colleton," Southern Agriculturist, N.S., V (January 1845), 19; J. M. Verdier, "Address Delivered Before the Agricultural Society of Beaufort," ibid., XII (September 1839), 461-62. On the use of religious terminology note rhetorician Whately's remark that it "has been supposed to carry with it an air of appropriate dignity and sanctity, which greatly adds to the force of what is said." Elements of Rhetoric, 206. Agricultural jeremiads abound with expressions of anxiety about growing materialism. See for example John B. O'Neall, “An Agricultural Address Delivered Before the State Agricultural Society, 29th December, 1842," in Proceedings, 196-97.

29 Seabrook, An Address Delivered at the First Anniversary Meeting of the United Agricultural Society of South Carolina, 6th December 1827 (Charleston, 1828), 3. 
immediate pecuniary consequences, but its great moral effects." Through such evocation of feeling agricultural oratory sought to achieve the purposes of all rhetoric: to influence men to think and feel what is right and thereby move them to do what is right. Nature, like God, the addresses advised, must be actively worshipped. Herein lay the imperative for agricultural reform. ". . . we ought to bear in mind," James Hamilton counseled, "that the great source of production is the earth; that in order to keep her in a kind temper for yielding, we must pay her tribute without stint." To manure the land, South Carolina's orators explicitly proclaimed, was to make an offering to God, as well as to Mammon. ${ }^{30}$

The agricultural orator thus sought to establish cognitive consistency in the minds of his listeners by identifying agriculture with all those configurations of belief and sources of meaning his compatriots seemed to regard as important. Indeed, the structure of the address was a movement from one to another of these frameworks of meaning, a juxtaposition of several sources of authority. Through its compatibility with both older and newer systems of belief, agriculture was offered as a bridge over the chasm of change. Here, the orator proclaimed, was a means of resolving conflicting ideological allegiances. By combining-both substantively and structurally-discussion of past achievement with that of future progress, by uniting religion and science, the agricultural oration associated reassuring tradition with dynamic innovation, deriving from each realm its own particular affective imperative, designed to infuse agriculture with new meaning. The agriculturist, the orator proclaimed, could be simultaneously wealthy and holy, religious and rational, traditional and modern. ${ }^{31}$

Carolinians, however, shared fears more immediate and perhaps more alarming than their anxieties about shifting foundations for belief in an era of change. The world seemed not just to be escaping easy comprehension; it threatened to slip entirely out of their control. "Dangers," Hugh Swinton Legare remarked to a friend, "are around and above and below and within our poor little State." The agricultural address in South Carolina reflected these peculiarly local fears and was therefore designed to resolve

so Quotations are in order from Turner, The Forest of Symbols: Aspects of Ndembu Ritual (Ithaca, 1967), 30; Hammond, "Anniversary Oration," 182; Hamilton, "An Address on the Agriculture and Husbandry of the South," Southern Agriculturist, N.S., IV (August 1844), 304 (quotation), 310-11.

31 This establishment of general frameworks of meaning uniting tradition and progress also characterizes the first portion of most northern agricultural addresses. It is in the second section, where specific applications of the principles were addressed, that the differences become striking. 
tension and conflict in the social as well as the cultural realm. At the same time, therefore, that its introductory synthesis of religion, science, and history offered a convincing framework of explanation for mundane events, the oration sought a more immediate social impact, and this effort structured the more pragmatic second half of the address. ${ }^{32}$

Spurred by their growing fears of disorder, Carolinians endeavored to reaffirm existing social arrangements by emphasizing the state's unity of material interest. To this end, agricultural orators attempted to identify the people of South Carolina with the land and to demonstrate that a particular social and economic system grew inescapably out of this special relationship. As Henry William Ravenel stated explicitly, "An agricultural people are always more strongly attached to the soil on which they have been reared. They become identified with it." Indeed, man's body itself, another speaker explained, was literally "composed of the materials of agriculture ...." The social order, the orators implied, was founded in nature and therefore must be at once legitimate and inevitable. ${ }^{33}$

But nature exerted her influence in another manner as well, decreeing not just the unity but the particularity of southern agriculturists. The soil of the South, its flora and fauna, were-like the social institutions that had grown out of them-specific to the region and dictated by its unique characteristics. "Peculiar climate, peculiar productions, and still more peculiar institutions,", William Elliott argued, rendered agriculture the fundamental determinant of the entire southern way of life, the source of the unity and distinctiveness of the southern people. "We, stand as agriculturists," Frederick A. Porcher proclaimed to the Black Oak Agricultural Society, "isolated from the mass of mankind " Growing political and ideological nonconformity was founded, Carolinians asserted, in the unchanging realities of the physical environment. ${ }^{34}$

Yet, to portray southern society as united and self-conscious was a rhetorical gesture, more prescriptive than descriptive. Emphasis on "homogeneity of interest," Ravenel explained, was spe-

32 Legare is quoted in Freehling, Prelude to Civil War, 5.

${ }^{33}$ Ravenel, Anniversary Address Delivered Before the Black Oak Agricultural Society, April, 1852 (Charleston, 1852), 9; Mikell, "Address," 14. Such an understanding of nature is what Mary Douglas calls "natural symbols," the perception of nature in terms of social categories. See her Natural Symbols: Explorations in Cosmology (New York, 1973).

${ }^{34}$ Elliott, The Anniversary Address of the State Agricultural Society of South Carolina ... November 30, 1848 (Columbia, 1848), 4; Porcher, "An Address," Southern Agriculturist, N.S., V (January 1845), 2. 
cifically calculated to persuade southerners to a "unanimity of action" in a state where even the leadership class was riven with conflict. By affirming the existence of a shared southern identity that had grown out of a common association with the soil, orators sought to compensate for existing divisions and to obviate the threat of emerging ones. ${ }^{35}$

A committee of the State Agricultural Society readily acknowledged the strong tendencies toward fragmentation within the Carolina elite when it observed in 1845 that "The habits of planters are those of separate action: they combine less than any other class of men. Each regards his plantation as his empire ...." These long-standing pressures toward disunity, moreover, had been greatly intensified by the fierce political conflicts of the early thirties. Unionists and Nullifiers had struggled bitterly within the state, and wounds incurred during the hostilities still smarted, serving as a significant divisive factor throughout South Carolina and within her leadership. Recurring national crises, such as the controversy later in the same decade over the effort to "gag" congressional discussion of abolition, continued to erode the solidarity of Carolina's master class. ${ }^{36}$

To a state that had long regarded unity as all important and had systematically eschewed the development of a party system because of the necessary division it implied, such developments seemed most alarming. Orators sought specifically to use agriculture as a diversion from these frictions. "Could we talk less about politics and more about crops?"' one speaker implored. In contrast to the "agitating" subject of political issues, orators found the topic of agriculture altogether "more calm, and peaceful"and therefore, more desirable. Political controversy, another orator warned, undermined that "unity of feeling, thought and action" so essential to defend the state and her peculiar institutions against what one planter called "the intonations of a gathering tempest." 37

Orators regularly avoided the difficulties posed by political questions by insisting upon subsuming them into a discussion of

35 Ravenel, Anniversary Address, 6.

36 "Proceedings of the State Agricultural Society of South-Carolina," Southern Agriculturist, N.S., V (November 1845), 413.

"' Quotations are in order from John B. O'Neall, "An Address Delivered Before the State Agricultural Society . . . 11th September 1844," in Proceedings, 217; R. A. Maxwell, "An Agricultural Address at the Anniversary Meeting of the Pendleton Farmers' Society, October 1844," Carolina Planter, I (June 1845), 265; William Taylor, "Anniversary Address, Delivered Before the State Agricultural Society . . . 30th of November 1843," in Proceedings, 206-207; Colleton, "Some of the Causes of the Decline and Fall of Most of the Agricultural Societies of South Carolina," Southern Agriculturist, VIII (March 1835), 114. 
agriculture. It was on this topic, "if any where," R. A. Maxwell proclaimed to an up-country gathering, that "all parties may unite on a common platform . . . .' In recognizing the unity of interest that underlay any political question or potential division, Carolinians could escape the "low and vulgar banners of party." Andrew P. Calhoun painted an appealing portrait of the way that an understanding of the central importance of agriculture would enhance the future of South Carolina. ". . . we will have society great and grand beyond description," he proclaimed, "-one homogenious [sic] interests [sic] extending through the whole. Every question started by demagogism in our midst, hushed-unity, concert, and strength will mark our councils." A focus on the importance of agriculture would, he implied, not just unify the planters. Class differences among all whites were defined as meaningless before this overwhelming commonality of interest. A demagogue's factional appeal to the masses could not succeed, Calhoun explained, in a society where the people understood their common identity. The hegemony of agriculture would thus ensure the hegemony of the planter, of his particular husbandry and its peculiar institutions. ${ }^{38}$

In its consideration of specifically Carolinian problems of social unity, the second half of the agricultural address often turned to the subject of slavery. As one orator explained, it seemed "naturally required of me" to discuss the system of human bondage. The advancement of a common agricultural interest as a means of suppressing political dissension thus addressed another agenda as well. Agriculture was not simply the means of support of the great majority of the population; it was the raison d'être for the slave institution upon which the social order was built. "The system of Southern Agriculture," as William Elliott acknowledged, "is dependent on and moulded by the institution of domestic slavery." Orators identified the people with the southern soil, the soil, in turn, with a particular sort of agriculture, and the agriculture, finally, with the peculiar institutions of the southern states. To improve husbandry was thus to defend slavery. As Whitemarsh B. Seabrook explained, "South-Carolina is emphatically an agricultural State. The prosperity and permanency of her domestic institutions are identified with its success. ... To encourage it, is a political duty . . . .",39

\footnotetext{
38 Maxwell, "An Agricultural Address," 265; Calhoun, "Address Delivered Before the State Agricultural Society . . . November 11th, 1856," Farmer and Planter, VIII (January 1857), 4.

30 Joseph E. Jenkins, "An Address Delivered Before the Agricultural Society of St.
} 
The language of agriculture became a kind of code for the discussion of slavery, a means of talking about the most sensitive political concern of the day in a manner ostensibly apolitical, a manner designed to obviate any sources of division on this allimportant subject. The orators' overwhelming concern with unity arose ultimately from anxieties about this very issue, about the future of the slave institution. Implicit within every agricultural address, these tensions frequently became explicit as well. As early as 1825 Seabrook warned that "the tenure by which we hold our slaves, is daily becoming less secure . . . ." Two decades later he found "Our domestic institutions . . . in imminent peril." Agricultural uplift was a crucial part of meeting this crisis, Seabrook explained, for "If, from unprofitable harvests, the servant should become a burden to his master, the shouts of the fanatic may yet be heard in our own domicil [sic]"'. Agricultural reform could be equated with the survival of both slavery and the South. The "existence and continuance" of the peculiar institution, one upcountry orator warned explicitly, "depend upon our agriculture." 40

Although only a few organizations actually titled themselves "Agricultural and Police Societies,"' a common dedication to upholding slavery was clear in the addresses delivered before every association. Mastery of slaves was on the one hand "a profound and difficult science" requiring the same level of learning and skill as any kind of animal husbandry. Yet slaves were human as well, undeniably a part of the social and moral realm. "A heavy weight of moral and religious responsibilities devolve ..." upon the southern planter, Robert William Roper reminded the Agricultural Society of South Carolina, "especially where a number of his fellow creatures are subject to his control." Proper administration of slaves, like a reformed agriculture more generally, was thus, as one orator concluded, not just a scientific but "a sacred duty." 41

And by its association with the universal importance of agriculture, slavery too became a focus of unity. Because everyone was in one way or another dependent upon South Carolina's agricultural

John's, Colleton," Southern Agriculturist, XI (August 1838), 404; Elliott, The Anniversary Address, 34; Seabrook, "From an Address Delivered . . 6th December 1827," Southern Agriculturist, IX (March 1836), 126.

${ }^{10}$ Seabrook, A Concise View of the Critical Situation and Future Prospects of the Slave-Holding States . . . (Charleston, 1825), 3; and Seabrook, An Essay on the Agricultural Capabilities of S. Carolina . . . (Columbia, 1848), 21; O'Neall, "An Address Delivered at Greenville, 11th September 1844," in Proceedings, 219.

"Manly, "An Address on Agriculture," 337; Roper, "Anniversary Address, Delivered . . . August 19, 1834," Southern Agriculturist, VII (November 1834), 568; James Hamilton, "An Address on Agricultural Husbandry," 312. 
productivity, the orators argued, everyone-whether or not he owned slaves-was dependent upon the peculiar institution. David F. Jamison explained this point of view to the state society. "The brunt of this conflict" with the North, he declared, "must be borne by the slaveholders. They constitute the most numerous class and are most directly interested in the issue. But who is the slaveholder? Or more properly, Who is interested in the institution of slavery? Every one, I answer, who is interested in the welfare, good government and prosperity of the South." Jamison, like most agricultural orators, sought to identify nonslaveholders as well as planters with the peculiar institution and here did so by the rhetorical trick of redefining the terms of the discussion. By insisting that slavery was indispensable to all southerners, he argued that through their identification with a slaveholding region even nonslaveholders became slaveholders themselves. ${ }^{42}$

From the transcendent realm of history, religion and science, the agricultural address thus narrowed its focus to specific issues, such as slavery, that troubled the state. Like traditional Protestant sermons, the orations moved from the general exegesis of doctrine to its particular mundane applications. The systems of meaning explored in the beginning of each address provided the language and the framework within which the details of Carolina's impending crisis were discussed; orators hoped to infuse the particular actions advocated in the second half of the agricultural addresses with the compelling force of the imperatives contained in the overarching systems of belief already outlined. Thus, they called their fellow citizens to united action in undertaking the moral, social and economic uplift of the state.

In its mission of inspiration and even conversion, the agricultural address was thus transformed from rhetoric into part of a quasi-religious ritual. Verbal action was intended to provoke behavioral response; both were part of the same continuum of social action. Like the Protestant sermon not just in general structure but in external context, the agricultural oration served as a central component in a gathering of the faithful; it was the focusing element in the meetings of the agricultural societies that began to proliferate in the thirties. Between 1826 and 1847 the number of these nearly tripled, from eleven to thirty-two, and a State Agricultural Society was created in 1839 to coordinate the expanding activities of the local groups. ${ }^{43}$

42 Jamison, Annual Address Before the State Agricultural Society, of South Carolina, (n.p., 1856?), 353.

43 For a discussion of the way that social ceremonies may be structured around linguistic events see Douglas, Natural Symbols, 44; and Basil Bernstein, ed., Class, Codes and 
The agricultural association provided a social setting and context for the agricultural address and even an embodiment of the values these orations expressed. The society meeting was to translate the action of words into the action of behavior. Agricultural organizations were intended to promote the unity of all South Carolinians, a unity that the orations had defined as both necessary and desirable. Because leaders saw agricultural improvement as indispensable to South Carolina's survival in the escalating sectional struggle they made an effort to enlist every citizen in the cause. Thus, they held agricultural festivals, advertised by widely distributed handbills; thus, they self-consciously named the two most prominent journals of the movement Southern Agriculturist and Farmer and Planter, emphasizing in the very titles the unity of all tillers of the soil. But from the first it was evident that the evangelism of agriculture was not easily to succeed-as many of its prophets had dared hope-in converting Carolinians of all classes to the gospel of improvement. Agricultural reformers therefore explicitly dedicated themselves, at least as an immediate goal, to the consolidation of the planter class within the state, an endeavor that dangerous political divisions originating in nullification had made especially urgent. "The constant interchange ... of sentiments and opinions between planters, from different sections of the country, which will be elicited," one advocate of organization explained, "will be a great mean of forming a closer union than has heretofore prevailed . . . ." Just as

Control (2 vols., London, 1971), I: Theoretical Studies Towards a Sociology of Language. On agricultural societies see Mendenhall, "A History of Agriculture," 228; and surviving records, including The Constitution, Acts and Proceedings of the Black Oak Agricultural Society . . . (Charleston, 1843); The Constitution and Bye-Laws of the Pendleton Farmers Society . . . (Columbia, 1820); Charleston County, South Carolina Agricultural Society of South Carolina Minutes, 1825-1860; Record of the Proceedings of the Beech Island Agricultural Club, 1846-1862; Darlington Agricultural Society Minutes, 1846-1884; Minutes of the Pendleton Farmers' Society, 1824-1919; State Agricultural Society, Columbia, Proceedings, 1855-1860 (all typescripts in South Caroliniana Library, University of South Carolina, Columbia, S. C.); William J. Ball Books; Elliott and Gonzales Family Papers; and James R. Sparkman Papers (all in Southern Historical Collection, University of North Carolina, Chapel Hill, N. C.); Black Oak Agricultural Society Minutes, 1842-1844, 1859, 1861, 1862 (South Carolina Historical Society, Charleston, S. C.); Public Improvements: Agriculture, Governors' Papers (South Carolina Department of Archives and History, Columbia). See also histories: W. A. Clark, ed., History of the State Agricultural Society of South Carolina (Columbia, 1916); C. L. Newmann and J. C. Stribling, Pendleton Farmers' Society (Atlanta, 1908); Cornelius I. Walker, A History of Agricultural Society of South Carolina . . . ([Charleston, 1919]); David Doar, A Sketch of the Agricultural Society of St. James, Santee, South Carolina (Charleston, 1908); William M. Frampton, The Agricultural Society of South Carolina (Charleston, 1931); J. M. Napier, Historical Sketch of the Darlington County Agricultural Society, 1816-1946 (n.p., 1946); History of the State Agricultural Society of South Carolina from 1839 to 1845, Inclusive, of the State Agricultural Society of South Carolina from 1855 to 1861, Inclusive, of the State Agricultural and Mechanical Society of South Carolina from 1869 to 1916, Inclusive (Columbia, 1916). 
agricultural oratory sought to replace partisan polemics, so gatherings of agricultural societies were designed to supplant political assemblies with their inevitable tendencies toward faction and discord. ${ }^{44}$

The societies themselves became almost exclusively the preserve of the planter class. When Virginian Edmund Ruffin spoke before the Monticello Society, he remarked that he "did not see one who appeared to be of the lower class,"' even though he expected such individuals to be "attracted by the plentiful barbacue [sic]". In the Pendleton Association-one of the few agricultural organizations to assume the humble appellation of Farmers' Society-the average landholding was 809 acres, while the average for the area was 426 . While only 28 percent of club members owned 250 acres or less, 43 percent of landholders in the vicinity possessed farms smaller than that size. Thus even in Pendleton, in the more egalitarian up-country region of the state, agricultural society members were the most substantial property holders. ${ }^{45}$

In most agricultural organizations, the form of the meetings was much the same, directly reflecting the outlook and values of this master class. An inspirational address by a leading citizen often opened the proceedings by lamenting Carolina's decline and asserting the need for both agricultural and moral reform. Individual members of the organization then spoke, affirming the principles of a reformed husbandry or offering witness of their personal conversion to scientific farming by describing their own experiments and innovations. Through this procedure, John S. Brisbane explained to the St. Andrews Association, "we not only may communicate any improvement made individually, but we excite a disposition to have something worth communicating, and arouse into action those dormant powers of investigation which otherwise would remain in torpidity. Who has not felt himself stimulated to exertion by the desire of gaining the applause of his neighbors ... [?]" To encourage such "emulation" more generally, agricultural clubs sponsored exhibitions and fairs and offered premiums for outstanding examples of produce or stock..$^{46}$

The societies sought to create an atmosphere of mutual improvement by encouraging competition and communal pressure. One of the vehicles for realizing this goal was the committees of

"4 Agricola, "Planters' Clubs," Southern Agriculturist, N.S., IV (November 1844), 402; "Extracts from an Address Delivered Before the Greenville Agricultural Society in August 1841," ibid., N.S., II (January 1842), 27-28.

${ }^{45}$ Ruffin, Private Diary, July 5, 1843, p. 251; Hall, The Story of Soil Conservation, 28.

${ }^{46}$ Brisbane, "An Address Delivered Before the St. Andrews Ashley and Stono Agricultural Association, July 1842," Southern Agriculturist, N.S., III (February 1843), 41. 
inspection that reported at society gatherings. These groups were appointed to investigate members' methods of husbandry. ". . . the fear of shame," Brisbane explained, "of being held up to view as negligent planters, will stimulate to exertions, which otherwise would not have been made." Despite the untidy appearance of his crop because of the outbreak of measles in his family, Mr. Crawford was forgiven by the Visiting Committee of the Fishing Creek Agricultural Society because his purchase "of a fine Berkshire pig" seemed "a sufficient index that, with him, the spirit of improvement is abroad." Like the classes within evangelical sects, the visiting committees of South Carolina's agricultural societies were designed to ensure that spiritual conversion to reform would not fail to be expressed in changed behavior. ${ }^{47}$

Following the reports of these inspections, agricultural meetings frequently dissolved for a "pic-nic," a feast of such magnitude as itself to serve as testimony to the potential bounty of the earthand the wealth of the planters who provided it. As with the premiums and committee visits, the planters here too vied with one another to display their agricultural success and social status, in this instance by providing the most sumptuous foods. At St. Helena Society meetings members rotated the responsibility for dinner, which eventually became so lavish that the organization decided to impose a fifty-cent fine on those who sent more than six courses of meat to the clubhouse. At the St. Andrew's Society each member contributed a single dish, but all had to be consigned to "the hands of the stewards, and by them arranged on the table" in order to prevent any individual from placing his contribution in a position of undue prominence on the buffet. While the societies sought to unify Carolina's planters and the agricultural interest in the state as a whole, they simultaneously provided an arena for the display and affirmation of the hierarchical structure of Carolina society and of its elite. The aggressiveness that the Carolina aristocrat exhibited in political contests thus appeared in the more "calm and peaceful" realm of agriculture as well. But here the planter could express his competitiveness in a less socially destructive manner, in a potlatch centered on food or in rivalry over success in husbandry. Just as the orations at these meetings articulated the system of values of the culture, so the activities that followed-the interaction among the planters, the reports of the inspection committees, and the "pic-nic"-served as the social expression of these values and as a ritual ratification of the Caro420.

17 Ibid., 42; "Report of the Fishing Creek Agricultural Society," III (November 1843), 
lina social order. ${ }^{48}$

Both the addresses and the societies demonstrate the peculiar combination of aristocratic and democratic allegiances that troubled mid-nineteenth-century Carolinians. The emphasis of the orations on the central importance of agriculture to the state denied the legitimacy of class conflict while simultaneously ensuring the preeminence of the planter. Yet fear of an emergence of class resentment is evident throughout the addresses. Speakers felt obligated to outline the allegedly nearly equal advantages offered to all classes by the southern way of life, thus implicitly acknowledging that democratic principles held some legitimacy. As they demonstrated their commitment to perpetuating their own preeminence, they felt curiously compelled to maintain that it did not exist.

Agricultural reform was an undertaking designed to meet the needs of Carolina's master class during an era of extended crisis; it served as an assertion of control by a class unsettled by economic difficulties at home, eroding political power within the nation, and doubts about the foundations of its own legitimacy. Through the rhetoric and ritual of agriculture South Carolina planters sought to shore up their confidence and security, transforming their power into authority, identifying it with images of social prosperity and of morality, rather than relying on the more objective realities of unquestioned economic or political superiority to support their dominance. Unexamined hierarchicalism could no longer win consent; Carolina's master class felt compelled to demonstrate that its preeminence was-paradoxically-democratic, as well as moral and rational in foundation.

In a similarly paradoxical manner, the agricultural reform movement was both a failure and a success. Agricultural historians looking back on objective conditions have found that actual improvement of land or methods of tillage was minimal and was for the most part restricted to those privileged planters who believed they could afford the luxury of experiment. Most Carolinians, ignoring entreaties on behalf of deep plowing and crop rotation, continued their destructive practices. Nevertheless, attitudes toward agricultural conditions changed out of all proportion to any actual amelioration of the situation. While some implacably realistic orators continued to assail Carolina agriculture, even these felt compelled to combat a growing sense of optimism about

18 See Willie Lee Rose, Rehearsal for Reconstruction: The Port Royal Experiment (New York, 1964), 117, for a discussion of St. Helena Society; "Second Anniversary of the St. Andrew's, Ashley and Stono Agricultural Association, April 3d, 1844," Southern Agriculturist, N.S., IV (June 1844), 211. 
successes of the reform movement. "Much has been said about improvement in agriculture," J. P. Barrott admitted to the Greenwood Society in 1852. But, he challenged, "we ask for the proof .... We talk much of improvement in agriculture," he concluded, "but it is all fudge . . . ."49

Most orators did not share his cynicism. "We now have," William Elliott proclaimed to the St. Paul's Society in 1850, "a marked and visible improvement in every department of business." There was justification for his belief that in important ways the situation had changed. With the rise of cotton prices in the early fifties Carolinians could afford to be optimistic. "Farmers are generally out of debt . . . ,' J. E. Byrd wrote in Farmer and Planter. A declining interest in agricultural improvement accompanied this new mood and was reflected in the demise of the State Agricultural Society, which stopped meeting after the fall of 1849 because of the inactivity among many of the local organizations that composed it. ${ }^{50}$

These changed attitudes about agriculture were in part a reflection of Carolina's revitalized faith in the social order that agriculture had come to symbolize. Improved prices affected Carolinians' perceptions of agricultural conditions, but these perceptions simultaneously reflected a larger social and political atmosphere. The acute nature of regional crisis in the years just before the Civil War seemed to require a level of confidence incompatible with intense criticism of agricultural and economic realities and prospects. To risk real reform, Andrew P. Calhoun explained in an 1856 oration, South Carolina had to feel secure, for only under such circumstances could she safely admit weakness and acknowledge the need for change. Another citizen explained in Farmer and Planter that it was dangerous amid the upheaval following the Compromise of 1850 to contend "that neglect and dilapidation mark our internal condition. At this moment, when our gallant little state seems destined to fight, single handed, the battle of the South, we have need of all our courage, all our spirits, all our faith in Carolina." 51

Agricultural reform, they implied, was an undertaking suited to

4 J. P. Barrott, "Address Before the Greenwood Agricultural Society, October 30, 1852," Farmer and Planter, IV (January 1853), 8-9.

so Elliott, Address Delivered Before the St. Paul's Agricultural Society, May, 1850 (Charleston, 1850), 4; J. E. Byrd, "Agricultural Prospects," Farmer and Planter, II (May 1851), 54.

"1 Calhoun, "Address Delivered Before the State Agricultural Society, November 11th, 1856," Farmer and Planter, VIII (January 1857), 3-10; Carolina, “Mr. Junius Smith's Letter," ibid., II (March 1851), 20. 
an era in which crisis was less acute, an era of merely chronic difficulties, like those of the late thirties and forties, for example. It was a movement that could anticipate only long-term effects in building social unity and uplifting a distressed economy. When the northern threat seemed immediate-at the time of nullification, during the crisis of 1850-1852, and in the period of secession-the focus of concern of the planter class shifted to the more narrowly political issues it could use as its sectional defense within the arena of national government. The agricultural jeremiad, with its language of desolation and decline, conceded too much to the enemy and was thus supplanted by a political rhetoric emphasizing not the state's shortcomings but its successes, the emblems of its special favor with God. ". . . who will gainsay," demanded an orator, "that the Southern people of the American Union are the chosen race of modern times?" The special status that had so long been implied by the image of agricultural depression as corrective affliction was here at last realized as a full-blown southern nationalism. James Henry Hammond employed the now familiar synecdochic identification of the South with her agricultural staples in his proclamation of this burgeoning sectional confidence. Although in 1841 he had advised his fellow Carolinians to abandon the unprofitable cultivation of cotton, in $\mathbf{1 8 5 8}$ he felt the necessary assurance to proclaim to the United States Senate and the world at large, "you dare not make war on cotton. . . . Cotton is king."" 52

In the comparatively quiet years of the mid-fifties the agricultural reform movement had reemerged briefly with the reestablishment of the State Society in 1855 , but this effort, like its predecessors, was to fail and to disappear beneath the overwhelmingly political concerns of its era. Despite its failure to improve agricultural practice, the reform movement contributed to an important shift in outlook within the state. With the final crisis of Lincoln's election Carolina's master class was sufficiently convinced of the legitimacy of its authority and the viability of its way of life to defy national law and opinion and, ultimately, federal troops. South Carolina's planters were able to agree to withdraw from the Union without creating the internecine division that had appeared during nullification, and they succeeded as well in securing the acquiescence-if not the enthusiastic support-of the rest of the citizens of the state. Although the lands and practices of the state's

\footnotetext{
${ }_{32}$ Arthur Simkins, An Address Before the State Agricultural Society of South Carolina ... November 1855 at Columbia, S. C. (Edgefield Court House, S. C., 1855), 7-8; Hammond, Selections from the Letters and Speeches of the Hon. James H. Hammond (New York, 1866), 317.
} 
husbandmen were for the most part unchanged, attitudes were not. The planter class found in 1861 a unity and effectiveness of action that had eluded it thirty years before. The rhetoric and rituals of agriculture had played an important role in establishing this symbolic consensus and social solidarity. ${ }^{53}$

Attribution of such crucial significance to tediously repetitive, long-winded, stereotyped orations may seem bewildering, if not perverse. Yet it is their very formulaic quality that renders these addresses so suggestive to the historian, for it implies that there existed a set of socially understood and shared rules about the meaning and purpose of the orations. They are not simply random pronouncements but are rather a group product, a verbal genre, and therefore a social form. In this rural society the kinds of communication and interaction that form the essence of any culture were severely limited by geographic distances and by a level of illiteracy that inhibited the development of a periodical press or a large reading public. Thus, the verbal genres of oratory were of special importance in the Old South. As one historian has remarked, "It is doubtful if there has ever been a society in which the orator counted for more than he did in the Cotton Kingdom."'54

Yet an emphasis on verbal forms seems unfashionable, given the reaction by historians of recent years against their discipline's conventional reliance on texts in its interpretations of the past. Such approaches, scholars have justly argued, neglect the "inarticulate" masses, the less privileged orders of society who did not leave extensive written records. But this enthusiasm for the "history of the inarticulate"' has produced an unwarranted aversion to use of documents and a self-defeating blindness about new ways to interpret them. Not every verbal artifact is an abstract and intellectualistic treatise irrelevant to the society in which it appears. Speech is a form of social action, goal-directed and socially organized in the same way as voting or any other sort of behavior. The "new social history," with its emphasis on interdisciplinary methods of retrieving the experience of the inarticulate, has important implications for a new history of the articulate as well.

\footnotetext{
ss Channing, Crisis of Fear, summarizes the events of secession in South Carolina. For a specific study of the way the planters of the state dominated the secession convention and won their way see Ralph A. Wooster, The Secession Conventions of the South (Princeton, 1962), 11-25.

${ }^{54}$ William Garrott Brown, quoted in Waldo W. Braden, ed., Oratory in the Old South (Baton Rouge, 1970), 3.
} 
Clifford Geertz, perhaps the most prominent anthropological influence on recent historians, has advised scholars to treat behavior like a text. But perhaps for our purposes, we should invert this prescription. Possibilities for a new history of the articulate rest in treating texts like behavior. When these texts appear-as do agricultural orations-in recurrent and identical forms, they become a new sort of aggregate data, governed by social rules and suffused with cultural meaning. As the central performance in the ritual of the agricultural societies, these orations are symbolic social forms, part of a larger pattern of action and context of meaning that stretches out through society meetings into South Carolina civilization more generally. In part, the rhetoric of agriculture was designed to impel men to reformist action in the world outside them. But, at the same time, these symbols sought to reaffirm and refine the conceptual categories inside men's heads, a process that had profound effect upon the outlook of the antebellum Carolinian, the nature of the world he saw, and, thus, the way he subsequently acted within it. In these two senses-by manipulating both the world and the words that defined it-the language of agriculture became a form of cultural action. Words indeed took on, as Edmund Rhett had suggested, "the power of things." 55

ss Geertz, The Interpretation of Cultures, 448. See also Paul Ricoeur, "The Model of the Text: Meaningful Action Considered as a Text," Social Research, XXXVIII (Autumn 1971), 529-62. Treating texts like behavior has, of course, been the foundation of the work of Kenneth Burke and Quentin Skinner. Rhett, "Agricultural Address," 714. 